\title{
Blogs as a Means to Enhance Writing Skills in EFL Classes
}

\author{
$\underline{\text { http://dx.doi.org/10.3991/ijet.v11i04.5430 }}$ \\ M.V. Kuimova and O.D. Zvekov \\ National Research Tomsk Polytechnic University, Tomsk, Russia
}

\begin{abstract}
The current trend of higher education is the increasing share of independent individual and group work of students, as well as their practical and creative work. All these inevitably lead to the introduction of innovative educational technologies aimed at reaching syllabus goals. An active use of information and communication technologies enhances the learning in a content area and can be a great help to maintain the desired level of students' education. It allows advanced, diverse learning, drives motivation, creativity and learning outcomes. The authors make a review of the research on the use of blogs in foreign language teaching, discuss their benefits for both teachers and students, and share their experience of using blogs to promote learners' writing skills.
\end{abstract}

Index Terms-blogging; foreign language teaching; Internet technology; students' self-study; writing skills.

\section{INTRODUCTION}

Intensification and modernization of education require the introduction of innovative technologies aimed at the development of creative thinking, productive imagination, memory, attention and cognitive activities of university alumni. Blogging is among these innovative technologies.

\section{RELATED WORK}

Computer technology and the Internet can be easily integrated into a language classroom and provide meaningful writing opportunities [1]. Researchers say that the integration of electronic communicative practices in foreign language classrooms helps learners acquire new knowledge and develops intercultural competences [2], contributes to the development of writing skills and makes information sharing more challenging, meaningful and interesting [3, 4, 5]. Blogging, as a teaching strategy, provides a motivating learning environment, creates additional opportunities for language learning and furthers learners' independence [6]. The use of blogs in foreign language teaching encourages learners' creativity, interaction, sharing of ideas and comments, and motivates learners to build their writing skills [7]. Blogs help connect with an online community, further self-expressiveness and provide an opportunity to continue learning outside the classroom [8.]

\section{RESEARCH DATA}

The main objective of foreign language teaching is the formation of communicative competence and the ability for intercultural interaction; other goals (educational, developmental, etc.) are realized in the course of this primary objective. The specificity of the subject "foreign language" is that the leading components of the contents of foreign language teaching are not the principles of science, but different language skills: speaking, listening, reading and writing. Various teaching methods, innovative technologies and practice are necessary to master these skills. The integration of Internet technology in the educational process is a promising direction in education. The Internet opens up tremendous opportunities for any information, including authentic materials. In addition to text information, Internet technologies allow the use of audio files, videos and graphics, which greatly stimulate the learners' activity. Global network helps to organize discussions between learners and teachers not only within the university, but also attracts learners of other universities, regions and countries. Modern information and communication technologies (ICT) enable to enhance training activities, promote communication and develop the culture of independent students' work. The need to use ICT is also due to the continual increase in the volume of information that must be studied and processed in the course of training. Moreover, the practice of ICT in teaching foreign languages contributes to the optimization of the teaching process and allows to:

- access and manipulate large amounts of information;

- form information culture;

- use information sites and authentic modern Internet resources;

- make learning differentiated and individual;

- provide training materials in print, graphic, charts, audio, video and animated form;

- bridge the gap between theoretical knowledge and actual application of the studied material;

- automate the system of monitoring correction and evaluation of learners' knowledge;

- organize independent work;

- enhance learners' creative potential;

- carry out distance education.

Currently existing communication Internet technologies, which can be used in foreign language teaching, are divided into two groups:

- synchronous (enabling to communicate in real time. e.g. chat, forum, video and audio conference, etc);

- asynchronous (communication with a time delay. e.g. discussion forums, websites, blogs, etc.).

A blog (weblog) is a user-friendly, easily created website that can be used for learning in different disciplines and in various levels. In educational process, blogs can be used as a platform for: 
- training on primary and/or additional courses;

- distance training courses;

- additional educational resources;

- consultations;

- various types of discussions;

- learners' research activity.

The main purpose of a blog is to attract the reader's attention to the discussed issues. Blog can be the source and storage of various educational materials (essays, creative works, notes, reports, news, lists of hyperlinks on the studied topic, etc.) and an effective medium for intercultural communication. Blog allows combining the studied academic material with an entertaining text, audio and video. A.P. Campbell identifies three types of blogs used in foreign language classes:

- tutor blog (contains course information, assignments, homework, etc. It is usually run by teachers);

- class blog (mainly used for discussions. It is run by teacher and learners);

- learner blog (learners' personal online space. Teacher facilitates learners to develop their blog, write and comment on their interests, etc.) [9].

Nowadays, blogs are popular among students owing to the novelty of the technology. Compared with other information technology used in teaching, blogging technology has several advantages. It serves to:

- introduce a creative approach to the organization of learning;

- foster a feeling of community and build a closer relationship between learners;

- encourage online communication;

- promote out-of-class communication;

- develop the skills to analyze and synthesize information;

- improve writing skills;

- provide extra reading;

- improve learning outcomes.

Introduction of technology and blogging activities in foreign language teaching allows learners to work at their own pace and provides opportunities for:

- authentic learning environment for real communication;

- communication and development of intercultural competence;

- learners' active involvement in the language and overcoming the language barrier;

- explaining and reasoning their opinion;

- increase of learner's writing amount;

- learners' creative activity;

- motivating learners to study a foreign language and culture;

- using a foreign language and the Internet to meet learners' cognitive interests;

- sorting understanding, uncovering new ideas and drawing conclusions [3, 10, 11, 12, 13].

Blogs allow real dialogue with a large number of people who read the blog posts and leave their comments, including those with native speakers. Learners themselves control the process of learning by actively seeking the information and getting comments from other people. Blogs can be used as portfolios of learners' written works. Meanwhile, the integration of blog technology in the educational process helps a teacher to solve a number of challenges. It:

- develops cooperation in the group and promotes closer relations between learners (learners share information about themselves, their interests, and comment on what others have written, which may contribute to a sense of solidarity among the members of the group);

- forwards learners to potentially useful Internet resources and appropriate to their level. Learners find an effective solution to the problem proposed by the teacher through the Internet resources;

- provides learners with extra reading and writing practice;

- helps to find a real audience for what learners write;

- organizes extra-curricular discussions;

- allows shy students to speak on their blog:

- helps develop writing skills and improve the style of writing, as learners are interested in their statements being written correctly.

On the whole, blog technology consists of the following stages:

- preparatory (technical) stage (teacher introduces learners to the peculiarities of using blog technology, removes technical difficulties);

- inception (teacher announces the plan for the work (e.g. month, semester, etc) with a list of dates for the performance of the tasks and evaluation criteria of each type of work);

- procedural (teacher determines the frequency and volume of the compulsory individual publications. Learners place their publications in the blogs, discuss, comment on and evaluate each other's work. The task of the teacher at this stage is to control and direct learners' activities);

- evaluating (two types of control can take place: selfevaluation of students at the end of the course in the form of comments on personal blogs in which they express their opinions on the content of the course as well as suggestions for optimizing the learning process; teachers; evaluation on the basis of the evaluation criteria for each type of job).

The teacher should motivate and keep the interest of learners to blogging, encourage and promote their work, reading and commenting on the posts of their classmates, discuss with them the information in blogs and check their writing [14]. It is necessary to develop in learners the habit of blogging (e.g. weekly) and give them the following recommendations to make a blog lively:

- use catchy headlines (short and attractive);

- try to make the blog at least partially non-standard (for example, use quotes to reflect the theme of the message) and monitor the style to attract and hold the readers (no one wants to die of boredom reading a blog. You should try to attract those readers who may 
not be familiar with the subject about which you write in your blog);

- leave links to something interesting on the Internet to the readers;

- respond to comments on the blog;

- be bold to stand up and state your views.

\section{DisCUSSION AND RESEARCH}

To evaluate the efficacy of blog technology on students' learning achievements, we took two groups of students (experimental and control; 20 students in each) where students of the experimental group used blogging during entire semester. The work with blogs was divided into three stages:

1. preparatory. Learners:

- study the tasks, dates of their performance and evaluation criteria;

- register their blogs;

- study terms and guidelines for publishing their materials on the blog.

2. procedural:

- discussion, search and selection of the material;

- processing, systematization, analysis, and synthesis of the material;

- writing and publishing of the written work;

- monitoring the learners' independent work;

- remote discussion of classmates' written works in personal blogs (learners comment on the content, structure, coherency and language accuracy of their classmates' blogs, etc);

- monitoring the learners' independent work and their participation in the discussion of written works.

3. evaluation:

- self-evaluation (students evaluate their work, discuss the problems they encountered and voice what they need to do to improve their work next time);

- teacher scores the learners according to the predetermined criteria.

We developed the following criteria to evaluate the work of learners with their blogs:

1. content:

- independent thought and creative approach to the issue;

- figurative language devices (idioms, metaphors, similes, puns, hyperboles, etc);

- respond to comments.

2. language. Use a wide range of:

- vocabulary and grammar;

- coherent devices.

3. structure:

- division into paragraphs;

- presence of images to support the content;

- pleasant color-grade.

4. references to useful websites (presence or absence).

$85 \%$ of the students of the experimental group expressed a positive attitude towards personal blogging. They noted that a blog provides opportunities to com- municate in the Internet, write for their peers (not just for their teacher), learn from each other and get feedback not only from a teacher, but also from their classmates. However, $15 \%$ of the respondents dropped a hint of doubt if their blogs are useful in the Internet.

The students of the experimental group showed better writing skills in the final test $(35 \%)$. Moreover, we interviewed the students to know their opinion of blogging. They noted that it helped them:

- develop writing skills (55\%);

- build confidence in their writing (45\%);

- develop reading skills (35\%);

- communicate useful information (25\%).

\section{CONCLUSION}

Thus, the use of blog technology in a foreign language classroom helps teacher be abreast of current educational technologies, organize the process of learning, create opportunities to practice the language, increase learning interest, develop writing skills and promote communication skills. Moreover, learners can come into intercultural communication with native speakers and thus receive reliable information about culture of another country, young people's lives, their interests and hobbies, etc.

\section{REFERENCES}

[1] J.A. Arani, "Teaching English Medical Writing in a Blended Setting", International Journal of Emerging Technologies in Learning, vol. 7, No 4, 2012, pp. 34-37. http://dx.doi.org/10.3991/ ijet.v7i4.2253

[2] S. Melo-Pfeifer, "Blogs and the development of plurilingual and intercultural competence: report of a co-actional approach in Portuguese foreign language classroom", Computer Assisted Language Learning, vol. 28, issue 3, 2015, pp. 220-240. http://dx.doi.org/10.1080/09588221.2013.818556

[3] R.Ş. Arslan, "Integrating feedback into prospective English language teachers' writing process via blogs and portfolios", Turkish Online Journal of Educational Technology, vol. 13, issue 1, 2014, pp. 131-150.

[4] P. Krish, T. Vikneswaran and Hussin, S. 'Exploiting blogs in the ESL classroom", Pertanika Journal of Social Science and Humanities, vol. 22, issue February, 2014, pp. 97-110.

[5] N.E.M. Said, M. Yunus, L.K. Doring, A. Asmi, F. Aqilah and L.K.S. Li, "Blogging to enhance writing skills: A survey of students' perception and attitude", Asian Social Science, vol. 9, issue 16 SPL, 2013, pp. 95-101.

[6] A. Nicolaou and E.K. Constantinou, "Blogging revisited: The use of blogs in ESAP courses", Lecture Notes in Computer Science (including subseries Lecture Notes in Artificial Intelligence and Lecture Notes in Bioinformatics) 1st International Conference on Learning and Collaboration Technologies, LCT 2014 - Held as Part of 16th International Conference on Human-Computer Interaction, HCI International 2014; Heraklion, Crete; Greece; 22 June 2014 through 27 June 2014. vol. 8523 LNCS, issue PART 1, 2014, pp. 95-106. http://dx.doi.org/10.1007/978-3-319-07482$\underline{5 \_10}$

[7] R. Vurdien, "Enhancing writing skills through blogging in an advanced English as a Foreign Language class in Spain", Computer Assisted Language Learning, vol. 26, issue 2, 2013, pp. 126143. http://dx.doi.org/10.1080/09588221.2011.639784

[8] D. Huffaker, "The educated blogger: Using Weblogs to promote literacy in the classroom", First Monday, vol. 9, issue 6, 2004. Date Views 23.12.2015 http://firstmonday.org/ojs/index.php/fm/ article/view/1156/1076.

[9] A.P. Campbell, "Weblogs for Use with ESL Classes", The Internet TESL Journal, 2003. Date Views 23.12.2015 http://iteslj.org/Techniques/Campbell-Weblogs.html.

[10] R.Ş. Arslan, "Integrating Feedback into Prospective English 


\section{SHORT PAPER \\ Blogs as a Means to ENHANCE Writing SKILls IN EFL Classes}

Language Teachers' Writing Process via Blogs and Portfolios", TOJET: The Turkish Online Journal of Educational Technology, vol. 13, issue 1, 2014, pp. 131-150.

[11] M.M. Nepomuceno, "Writing Online: Using Blogs as an Alternative Writing Activity in Tertiary ESL Classes", TESOL Journal, Vol. 5, 2011, pp. 92-105.

[12] C. Trajtemberg and A. Yiakoumetti, "Weblogs: A tool for EFL interaction, expression, and self-evaluation", ELT Journal, vol. 65, issue 4, 2011, pp. 437-445. http://dx.doi.org/10.1093/elt/ccr015

[13] M. O'Connor, “The Impact of Participating in a Class Blog on the Writing of a Struggling Adolescent Learner", Journal of Classroom Research in Literacy, vol. 4, 2011, pp. 40-49.

[14] D. Moon and D.K. Lim, "Using Weblogs in Foreign Language Classrooms: Possibilities and Challenges", International Journal of Software Engineering and Its Applications, vol. 7, No. 5, 2013, pp. 121-128. http://dx.doi.org/10.14257/ijseia.2013.7.5.12

\section{AUTHORS}

M.V. Kuimova is with National Research Tomsk Polytechnic University, Tomsk, Russia (e-mail: mkuimova@mail.ru).

O.D. Zvekov is with National Research Tomsk Polytechnic University, Tomsk, Russia.

Manuscript received 02 January 2016. Published as resubmitted by the authors 07 February 2016. 